\title{
FANON, JORNALISTA DA JUSTIÇA SOCIAL E DA LIBERTAÇÃO, E suas aproximaçóes com a Bioética global de PotTer
}

\author{
Anor Sganzerla ${ }^{1}$ \\ Ivo Pereira de Queiroz ${ }^{2}$ \\ Rodolfo Stancki Silva ${ }^{3}$
}

Resumo: As grandes corporaçôes de comunicação, no Brasil, operam como construtoras de sentidos, por meio de narrativas sintonizadas com os interesses de grupos e atores sociais, com desprezo para as demandas e os direitos dos setores populares. Uma prática semelhante de comunicação foi vivenciada por Frantz Fanon, na África. No entanto, o ativista conseguiu fazer da sua práxis jornalística um instrumento a serviço da justiça e da libertação de povos africanos oprimidos. Essa prática libertária de Fanon identifica-se com os ideais da bioética global, criada posteriormente por Van Rensselaer Potter. Frente a esse cenário, esta reflexão quer investigar em que sentido a práxis jornalística de Fanon, durante a guerra de libertação argelina, em busca de justiça social e de libertação, se identifica com os fundamentos da bioética global proposta posteriormente por Potter. A análise consiste numa argumentação de caráter analítico-dedutivo. Se, com a bioética global, Potter procurou restaurar um sentido humano da práxis científica e tecnológica, Fanon buscou esse objetivo como comunicador social e médico.

Palavras-chave: Bioética global. Jornalismo. Justiça Social. Libertação.

\footnotetext{
1 Pontifícia Universidade Católica do Paraná (PUC/PR), Curitiba, PR - Brasil. https://orcid. org/0000-0001-8687-3408 - E- mail: anor.sganzerla@gmail.com.

${ }^{2}$ Universidade Tecnológica Federal do Paraná (UTFPR), Curitiba, PR - Brasil. https://orcid. org/0000-0001-8059-4045 - E-mail: ivoaxer@gmail.com.

3 Universidade Tecnológica Federal do Paraná (UTFPR), Curitiba, PR - Brasil. 6 https://orcid. org/0000-0002-3788-8555 - E-mail: stancki@gmail.com.
}

https://doi.org/10.1590/0101-3173.2022.v45esp.11.p185

This is an open-access article distributed under the terms of the Creative Commons Attribution License. 


\section{INTRODUÇÃo}

A produção do jornalismo no Ocidente, na década de 1950, já era marcada como uma prática comercial, em defesa dos interesses de certos grupos e atores sociais. Nesse mesmo período, Frantz Fanon, na África, fez do exercício jornalístico um instrumento de tomada de consciência e de libertaçáo de um povo, dando voz àqueles que eram oprimidos.

A difusão das tecnologias de impressão no Ocidente, contudo, identifica Peter Burke, estas proporcionaram fortes impactos sociais e contribuíram para proliferar ideais contestatórios. Nas palavras do historiador: "[...] no campo da política, como no da religiáo, a imprensa, especialmente os jornais impressos, encorajou a crítica e até a revolução, como no caso da Inglaterra em torno de 1640 e da França em 1789.” (BURKE, 2008, p. 73).

Assim, ao mesmo tempo que atuava para ampliar a democratização do saber, acrescenta Burke, a mídia impressa era usada para fortalecer poderes institucionais, e os governos passaram a adotar a nova tecnologia para se organizar, com a sistematização de seus processos de divulgação e coleta de informaçóes (BURKE, 2008, p. 68). Comerciantes especializados em editoração começaram a regular o mercado literário, garantindo monopólios sobre determinadas obras e abrindo as portas para que, em certas regiôes, o Estado passasse a autorizar o que podia ser publicado (BRIGGS; BURKE, 2006, p. 62).

O processo que se seguiu foi o aparecimento de novos dispositivos e sistemas, os quais buscavam facilitar - e, por vezes, controlar - os processos comerciais, que "[...] ficavam cada vez mais dependentes de comunicaçáo de informaçóes." (BRIGGS; BURKE, 2006, p. 62). Com isso, o jornalismo passou por uma transformação que o caracterizaria com o duplo papel de esfera pública, ou seja, de debate e de produto típico do capitalismo. De acordo com Genro Filho, a chave para entender essa discussão é o conceito de cidadania, porque a produção jornalística é fundamental para garantir a participação social do público na democracia liberal. Para Genro Filho (1987, p. 191-192), a cidadania burguesa “[...] implica uma situação prática e efetiva de universalidade dos indivíduos. Uma universalidade que, em graus variáveis, vai atingir a todos. Mas essa cidadania está comprometida com a desigualdade econômica, social e política."

Se, por um lado, a produção de notícias efetivamente atuou no avanço de ideias democráticas, no mundo moderno, a noção de que os 
jornais seriam espaços de circulação livres de ideias, usualmente esbarra nessa nova complexidade industrial e econômica (MEDINA, 1988, p. 18). Afinal, a difusão de informaçóes passou a fazer parte de uma lógica comercial, regulada por códigos profissionais ditados por quem mandava no mercado de informaçôes.

O conhecimento tecnológico ajudou a baratear os custos, o que levou ao aumento do número de leitores. Como uma produção de um sistema tipicamente liberal, os jornais estabeleceram com o público uma relação de produção-consumo. Isso, evidentemente, afetou a maneira de se produzir o conteúdo noticioso. Afirma Marcondes Filho (1989, p. 32) que, uma vez que a imprensa centra sua "[...] atividade econômica em direção ao modo capitalista de organizar a produçáo, tende cada vez mais a trabalhar seu produto segundo as imposiçôes da estética e da mercadoria.”

A busca por um público consumidor, o qual garantiria poder aos grandes empresários da imprensa, está na base do aparecimento do jornalismo popular e sensacionalista. Até então, os jornais que circulavam em certos países, como a Inglaterra, a França e os Estados Unidos, eram primordialmente voltados para a política e/ou para a economia.

Segundo o pesquisador Michael Shudson (2010, p. 34), nos Estados Unidos, são os jornais populares que conceberam o conceito moderno de notícia: "[...] pela primeira vez, os jornais norte-americanos transformaram em uma prática regular a publicação de notícias políticas, não apenas internacionais, mas domésticas, e não somente nacionais, mas locais."

É nesse momento que se populariza o jornalismo policial, além da própria ideia de que a notícia é o relato de um fato extraordinário. Como eram vendidos a um centavo, esses veículos eram chamados de penny press nos Estados Unidos. Na Europa, a raiz dessa imprensa sensacionalista era um fenômeno que os franceses chamavam de fait divers.

De acordo com Stephens, desde o século XVI, existiam publicaçôes especializadas em fofocas e tragédias. Parte delas são uma continuidade da literatura de cordel e dos trovadores que circulavam pela Idade Média, entretendo o público com histórias peculiares. Com a imprensa tipográfica, essas informações foram postas à forma de notícias e "[...] se revelaram agressivas, e até grosseiras, em seus esforços para atrair leitores.” (1993, p. 224). 
A fórmula dos penny press e dos fait divers seria adotada, em menor ou maior escala, no mundo inteiro. Tornou-se a base do jornalismo sensacionalista, como o conhecemos no Brasil, por vezes caracterizado como imprensa "marrom" ou "amarela". Não raro, esse tipo de narrativa jornalística é vista como uma espécie de "vilâ", a qual atrapalha a pretensa função social dos jornais em manter a sociedade informada e garantir, assim, o equilíbrio do regime democrático.

Décadas mais tarde, esse comportamento corroboraria as críticas dos teóricos da Escola de Frankfurt, com a alegação de que os meios de comunicação entregam conteúdos imediatos, os quais são feitos para "[...] empenharem unicamente o nível superficial de nossa atenção." (ECO, 2004, p. 41). Para o escritor Umberto Eco (2004, p. 42), essa perspectiva mais apocalíptica da cultura de massa e, consequentemente, do jornalismo, surge como parte de uma "[...] superestrutura do regime capitalista, usada para fins de controle e planificação coata das consciências."

Antes do aparecimento do jornalismo popular, no século XIX, os textos noticiosos não faziam uma distinção clara entre a ideia de informaçáo e opinião. Lage (2011, p. 10) afirma que, por muito tempo, o jornalista era aquele que atuava como um publicista, "[...] de quem se esperava orientaçóes e interpretaçóes políticas." Acrescenta o autor que, com a expansão do público e a popularização dos jornais, era preciso que os textos dialogassem com mais gente, "[...] aproximando-os dos usos orais ou cultivando figuras de estilo espetaculares.” (LAGE, 2011, p. 15).

A ascensão dos fait divers na Europa e da penny press nos Estados Unidos veio junto com uma percepção social de que os veículos que praticavam o sensacionalismo náo cumpriam exatamente o papel esperado da imprensa. Como um processo de autorregulação, na virada do século XIX para o XX, começavam a aparecer escolas para jornalistas e noçóes práticas que indicavam a necessidade de a informação jornalística reproduzir dados extraídos das fontes. Nesse sentido, os testemunhos dos fatos deveriam ser confrontados entre si, para se obter uma versão mais próxima possível da realidade. Com isso, ressalta Lage (2011, p. 18), “[...] a relação com as fontes deveria basear-se apenas na troca de informaçóes; e que seria necessário, nos casos controversos, ouvir porta-vozes dos diferentes interesses em jogo."

As agências de notícias, que surgem concomitantes ao novo jornalismo representado pelos veículos da penny press, auxiliam no processo de formação 
desse conceito moderno do texto noticioso, como o relato singularizado de um fato. Desde a metade do século XIX, grupos de imprensa usaram da recéminstalada rede de cabos de telégrafos para enviar informações dos cantos mais remotos do mundo.

A inovação, a qual está no centro do movimento de globalização que avançava naquele período, resultou na "[...] eclosão de um mercado de informação pensado em âmbito mundial orientado por interesses geopolíticos.” (MATTELART, 2002, p. 48). Isso contribuiu para que as notícias fossem publicadas com mais agilidade e alterou a lógica da produçáo noticiosa, ao propor "[...] uma linguagem homogeneizada, rápida, de fatos escassos, numa palavra, telegráfica." (TRAQUINA, 2005, p. 54).

A ideia de que o texto jornalístico deve ser produzido como uma "pirâmide invertida" nasce nesse período. Segundo essa lógica, a base da pirâmide abrigaria as informaçóes mais importantes ou interessantes sobre um fato em um parágrafo que recebe o nome de lide (lead, em inglês). No fim da narrativa, associado à ponta da pirâmide, ficariam os dados menos importantes ou interessantes do acontecimento (LAGE, 2011, p. 16).

Como as informaçóes passadas por telégrafo necessariamente precisavam ser breves, elas deveriam ser restritas a uma descrição do fato, a partir de uma síntese, informando ao leitor "[...] quem fez o que, a quem, quando, onde, como, por que e para quê.” (LAGE, 2011, p. 27). O lide é a técnica que sustenta a tese de que o jornalismo é uma forma de conhecimento cristalizado. Afirma Adelmo Genro Filho (1987, p. 53): “[...] o lead permite que através da natureza lógica e abstrata da linguagem [...] seja retomado o percurso que vai do abstrato ao concreto, não pela via da ciência, mas pela reprodução do real como singular-significativo.” E acrescenta o autor que, desse modo, o real irá aparecer, não através da teoria que vai apanhar o "[...] concreto pela sua reprodução lógica, mas recomposto pela abstração e pelas técnicas adequadas numa cristalização singular e fenomênica plena de significação, para então ser percebido como experiência vivida." (GENRO FILHO, 1987, p. 153).

Em outras palavras, o lide - enquanto relato objetivo e singularizado do fato - integra um jogo de significados, nos quais a leitura do texto noticioso precisa ser contextualizada pelo leitor, a fim de ser percebida como uma experiência do cotidiano. Por meio das notícias, os indivíduos se informam sobre questóes fundamentais para sua vida em sociedade. 
Luiz Gonzaga Motta (2006) afirma que esse consumo é importante, porque o mundo contemporâneo é complexo demais para que as pessoas dependam só de seu círculo social, de sorte a encontrar e partilhar informações importantes. A apreensão da realidade, portanto, se torna tecnologicamente mediada por certos processos, como o jornalismo. E, como se trata de uma percepção, a linguagem jornalística se torna uma ambiguidade, aberta a interpretaçóes e apropriaçóes.

Essa maneira de pensar e produzir o conhecimento jornalístico encontrou fissuras, ao longo do tempo. Desde a Idade Moderna, há setores da imprensa - menos capitalista e comercial do que o retratado acima - que trabalham com espaços de resistência. Nessa mídia alternativa, a singularidade da qual trata Genro Filho (1987) é menos relevante do que a necessidade de conscientização.

Em um artigo sobre o tema, o pesquisador Adair Bonini defende que existem espaços de produção, como a comunicação comunitária e escolar, os quais usam da mediação do jornal para seguir lógicas de produção de conhecimento bastante diversas. Tais projetos são "[...] contra-hegemônicos em diversos graus de oposição, a depender dos grupos e práticas aos quais estejam ligados." (BONINI, 2017, p. 175).

Frente a essas mudanças históricas ocorridas nos objetivos da imprensa, queremos contrapor a prática jornalística de Frantz Fanon, pois, para ele, o jornalismo não representava um relato dos acontecimentos do cotidiano, mas um instrumento para dar voz e consciência aos leitores, de modo que estes pudessem reconhecer a violência que estava sendo impetrada pelos franceses. Assim, esta reflexão quer saber: em que sentido a práxis jornalística de Frantz Fanon, durante a guerra de libertaçáo argelina, configura uma busca de justiça social e de libertação, permitindo, desse modo, entrever nela uma aproximação extemporânea dos fundamentos da bioética global apresentados por Potter, que pretendia restaurar o sentido humano da práxis científica e tecnológica em defesa da vida? Para alcançar essa meta, a reflexão se fundamentará em argumentação de caráter analítico-dedutivo. A sequência do texto é dividida em dois momentos: primeiro, com a apresentação da prática jornalística de Fanon, e, em seguida, com a exposição dos fundamentos da bioética global de Potter. Para concluir, a reflexáo procura aproximar e relacionar os ideais dos autores com o tema em debate. 


\section{Fanon e O Jornalismo de libertaÇão}

Esta seção acompanhará a trajetória de Fanon, em quatro momentos. No primeiro, observa a ruptura de contrato de trabalho com o governo francês e o engajamento revolucionário. $\mathrm{O}$ segundo momento, acompanha a crítica de Fanon ao episódio da condenação de Djamila Bouhired, em 1957, no periódico El Moudjahid. No terceiro, recuperamos vigorosas passagens de Fanon, descrevendo e denunciando os sistemas de tecnologia da dor que os franceses praticavam, nos laboratórios de tortura contra argelinos. Por fim, Fanon usa El Moudjahid para analisar a conjuntura do continente africano na luta contra o colonialismo e chamar seus irmáos à uniáo de forças, rumo à independência política.

Fanon trabalhou como médico-chefe da ala de psiquiatria do hospital de Blida-Joinvile, entre os anos de 1953 e 1956. Em função de seu vínculo empregatício, o qual the conferia prestígio e possibilidades de produção científica, recebera uma casa de excelente padrão. Contudo, a possibilidade de uma vida burguesa confortável foi rompida por sua inquietude, pois, à medida que foi tomando consciência da violência profunda que os colonialistas franceses impunham ao povo argelino, passou a sentir-se pessoalmente interpelado pelas contradições que lhe vieram à mente. $\mathrm{Na}$ carta de demissão encaminhada a Robert Lacoste, Ministro Residente, Fanon justificou a própria decisão, enfatizando: "[...] durante quase três anos dediquei-me totalmente ao serviço deste país e dos homens que o habitam. Não poupei nem os meus esforços nem o meu entusiasmo." (1980, p. 57). Mais adiante acrescenta Fanon (1980, p. 57): "[...] nada houve na minha acção (sic) que não exigisse como horizonte a emergência unanimemente desejada de um mundo válido.”

Depois de recordar os diligentes cuidados que teve para com as pessoas que atendeu, Fanon acusa os franceses, cuja prática colonialista representava o absoluto desrespeito à dignidade humana do povo argelino. Frustrado, avalia sua própria intervenção médica. Ao se referir ao Ministro Residente (1980, p. 58) questiona-o: "[...] mas o que significam o entusiasmo e o cuidado pelo homem, se diariamente a realidade é tecida de mentiras, de covardias, de desprezo pelo homem?" Descrente a respeito do trabalho que realizava, sob a égide da opressão colonial, indagou ao mandatário Robert Lacoste (1980, p. 58): “[...] de que servem as intenções, se a sua encarnação é tornada impossível pela indigência do coração, pela esterilidade do espírito, pelo ódio aos autóctones deste país?" 
Indignado, expôe ao Ministro Residente que a ação dirigida pelo governo francês naquele país significava, ao mesmo tempo, uma brutal contradição quanto aos princípios da psiquiatria comprometida verdadeiramente com a saúde da pessoa humana. Fanon (1980, p. 58) assevera que, "[...] se a psiquiatria é a técnica médica que se propóe permitir ao homem deixar de ser estranho ao que o rodeia, devo afirmar que o Árabe, alienado permanente no seu país, vive num estado de despersonalização absoluta. O estatuto da Argélia? Uma desumanização sistematizada." Toda a aposta absurda, acrescenta Fanon (1980, p. 58), era querer "[...] custasse o que custasse, fazer existir certos valores quando o não-direito, a desigualdade, o assassínio multiquotidiano do homem eram erigidos em princípios legislativos."

Para Fanon, a percepção do quadro sistemático de negação da humanidade do povo argelino foi como uma chama ardente a lhe queimar a consciência. As palavras do próprio autor perfilam o tom dramático do conflito interior que passou a experimentar:

[...] há longos meses que a minha consciência é palco de debates imperdoáveis. E a conclusão a que chego é a vontade de não desesperar do homem, isto é, de mim próprio [...] a minha decisão é a de não assegurar, custe o que custar, uma responsabilidade sob o falacioso pretexto de nada mais haver a fazer. (FANON, 1980, p. 59).

Fanon finalizou a carta formalizando o pedido de demissão da função de médico psiquiatra junto ao hospital de Blida-Joinvile. Em 1957, chegou a Túnis, na Tunísia (GEISMAR, 1972, p. 108), onde estava uma das bases da Frente de Libertação Nacional (FLN), passando a atender a pacientes no Hospital Charles Nicole (GEISMAR, 1972, p. 117).

Durante o engajamento na luta de libertação argelina, Fanon recebeu diversas atribuiçóes. Uma delas deu-se junto à equipe de imprensa que produzia o jornal El Moudjahid, ${ }^{4}$, no qual Fanon publicou vários artigos.

Em 1957, na cidade de Túnis, os revolucionários da FLN reorganizaram o periódico El Moudjahid. Uma edição, em árabe, tratava dos enfrentamentos na Argélia. Publicava-se outra edição, em francês, dirigida aos trabalhadores argelinos residentes na França (GEISMAR, 1972, p. 110 -111). Tinha em vista informar "[...] a um público mais vasto da África e

${ }^{4}$ El Moudjahid significa "Guerreiro Santo”. Numa tradução popular, indica mártir. A forma feminina é Moudjahidine ou Moudjahidina. 
Europa oriental.” (GEISMAR, 1972, p.110 -111). A finalidade dos artigos de El Moudjahid era "[...] registrar a história da revolução. Ao mesmo tempo, seus artigos ofereciam informação precisa sobre a contrarrevolução francesa." (GEISMAR, 1972, p. 112).

A Frente de Libertação Nacional (FLN) estimou em 1,5 milhão de pessoas mortas na guerra contra a França. Um dos episódios daquele enfrentamento levou Fanon a publicar um artigo, em novembro de 1957, intitulado "A propósito de uma defesa", no qual criticou um livro escrito por Georges Arnaud, alusivo ao julgamento da Moudjahidina Djamila Bouhired. Com efeito, a jovem fazia parte das mulheres argelinas revolucionárias, as quais se destacavam na luta de libertação. Foi ferida e presa portando documentos da FLN. Levada à França, foi julgada e condenada à morte, porém, a comoçáo internacional decorrente do acontecimento levou as autoridades francesas a libertá-la.

No comentário de Fanon ao livro de Georges Arnaud sobre o julgamento de Djamila, dentre outros aspectos, registra que a condenaçáo à morte de Djamila Bouhired seria um assassinato. E interpretou o riso de Bouhired $(1980,81)$, ao saber da sentença, afirmando que o riso "[...] não é nem bravata estéril nem inconsciência." Fanon lembrou as famílias argelinas enlutadas pela violência dos colonos franceses e fez notar que havia uma "certeza inabalável" que sintonizava o riso de Djamila e a reação do povo argelino, diante da sentença de morte: "[...] o povo argelino não manifestou qualquer surpresa ao saber da condenação à morte de Djamila Bouhired. Pois não há uma só família argelina que não tenha sido ferida, enlutada, dizimada em nome do povo francês." (BOUHIRED, 1980, p. 81).

O texto do autor é explicitamente parcial. Ele não economiza em confessar que fala desde o ponto de vista do povo argelino e a favor da luta de libertação. E denuncia a intromissão francesa na vida argelina, assoberbando o povo com terríveis tormentos. Nesse texto, evoca, na pessoa de Djamila Bouhired, o compromisso do povo argelino com uma outra Argélia, livre da opressão francesa. Assim, Fanon (1972, p. 81-82) frisa, no texto, que “[...] a mensagem de Djamila Bouharid inscreve-se na tradição dos argelinos mortos por uma Argélia independente. Os soldados do Exército Nacional, os homens e as mulheres da Argélia, estão comprometidos, como Djamila Bouhired", na luta implacável contra a dominação estrangeira. 
E, sem deixar qualquer margem à dúvida, Fanon acentua o tom mobilizador de seu texto, como chamamento do povo para somar forças no projeto da libertação. Por isso, mostra o vínculo estreitíssimo de cada pessoa argelina com Djamila Bouhired e seu ideal de emancipação, de superação da desgraça colonial. Todo o povo é Djamila Bouhired: "Haverá outras, e o povo argelino sabe-o. Sabe que a esperança do colonialismo francês é abalar a vontade nacional por meio destas execuçóes." (FANON, 1980, p. 82).

Noutro momento, Fanon voltou a atençáo aos centros de interrogatórios, descrevendo a filosofia da tortura ou tecnologia da dor, colocadas em prática pelos torcionários franceses naqueles laboratórios contra o povo argelino 5 . Ressalta Fanon $(1980$, p. 71$)$ que “[...] as práticas [...] monstruosas [...] impressionam pela sua generalização [as atitudes das] tropas francesas na Argélia insere-se numa estrutura de dominação policial, de racismo sistemático, de desumanização prosseguida de uma maneira racional. A tortura é inerente ao todo colonialista."

À medida que descrevia os processos e métodos opressivos dos colonialistas franceses, Fanon apontava o sentido emancipador do projeto popular de independência dos argelinos, cujo escopo último era a erradicação daquele modelo de exploração humana imposto pela França. Afirma Fanon (1980, p. 71) que a revolução argelina, em vista de uma libertação de todo território nacional, "[...] visa não só à morte deste conjunto, como à elaboração de uma sociedade nova. A independência da Argélia não é apenas o fim do colonialismo, mas desaparecimento, nesta parte do Mundo, de um gérmen de gangrena e de uma fonte de epidemia."

Por outro lado, era importante estar consciente de que não se tratava de um ou outro francês maldoso propagando ruindades na Argélia. Fanon cuida em evidenciar que se tratava de uma mobilizaçáo nacional francesa orientada à subordinação do povo argelino, para garantir a manutençáo da Argélia subjugada à França. Destaca Fanon (1980, p. 72) que o apelo era ao continente francês: "[...] a mobilização de várias classes, a convocação dos oficiais e sargentos, os convites ao sacrifício periodicamente lançados ao povo, os impostos e o congelamento dos salários empenharam toda a Nação francesa nesta guerra de reconquista colonial."

5 O artigo denomina-se "A Argélia perante os torcionários franceses." Foi publicado em El Moudjahid, n. 10 , setembro de 1957. 
A indignação argelina foi tomando corpo e se materializando em açóes opostas aos interesses colonialistas franceses. Em contrapartida, a retaliação ganhou tons dramáticos e, embora brutal e absolutamente desumana, a tortura foi posta em prática com uma política de controle assentada sobre bases científicas e tecnológicas. Por isso, o autor registrou que a tortura na Argélia “[...] não é um acidente, nem um erro ou uma falta. O colonialismo não se compreende sem a possibilidade de torturar, de violar ou massacrar. A tortura é uma modalidade das relaçôes ocupante-ocupado." (FANON, 1980, p. 73).

Em que pese a racionalização que perpassava os protocolos de tormentos impostos aos argelinos e argelinas castigados nas câmaras de dor, Fanon atendeu a franceses torturadores, apresentando graves anomalias comportamentais. Ao realizar o tratamento de tais pacientes, Fanon notou que havia um efeito bumerangue em andamento contra os torcionários franceses. Os algozes praticavam violência, nas relações familiares, como “[...] ameaças de morte dirigidas à mulher, sevícias graves sobre os filhos, insónias (sic), pesadelos, ameaças contínuas de suicídio.” (FANON, 1980, p. 73). No ambiente de trabalho também aconteciam irregularidades, dentre as quais "[...] as faltas profissionais de que se tornaram culpados, rixas com colegas, negligência no serviço, falta de firmeza, atitudes de desrespeito para com os chefes." (FANON, 1980, p.73). O psiquismo descontrolado dos torturadores exigiu intervençôes das autoridades, implicando "[...] muitas vezes cuidados médicos, transferências para outro serviço, ou mais frequentemente, mudança para a França." (FANON, 1980, p. 73-74).

A terapia desenvolvida junto aos torturadores desequilibrados deu a Fanon a causa dos problemas psicológicos sofridos pelos agentes produtores $\mathrm{da}$ dor da gente argelina. Fanon (1980, p. 73-74) náo poderia ser mais preciso, ao relatar as explicaçóes dos policiais: "[...] batem brutalmente nos filhos, porque julgam estar ainda com argelinos. Ameaçam as suas mulheres, porque 'todo o dia, ameaço e executo'. Não dormem, porque ouvem os gritos e os lamentos das suas vítimas."

A prática médica, atenta aos fundamentos científicos, para diagnosticar e agir em busca da cura, transparece nas observaçóes de Fanon, cujo interesse consiste em compreender a racionalidade da política de tortura. Ele compartilhou com seus leitores as percepçôes surgidas: "[...] possuímos actualmente pormenores acerca dos métodos usados pelos Franceses. Foi publicada uma grande quantidade de testemunhos, e inventariada a importante 
gama de técnicas." (FANON, 1980, p. 73-74). Mas, não foi fornecido “[...] nenhum elemento acerca da doutrina, da filosofia da tortura. Informaçóes chegadas à FLN esclarecem singularmente esta racionalização.” (FANON, 1980, p. 73-74).

Os estudos e observaçôes deram-lhe o roteiro da práxis da tortura como política de enfrentamento da luta por liberdade e soberania do povo argelino. Orientados por uma metodologia estudada por autoridades policiais, os torturadores recebiam prisioneiros(as) argelinos(as) e colocavam em prática o roteiro de investigação. Depois de o "[...] patriota ser preso, ele era levado para as instalaçôes da PJ. Não se lhe fazem perguntas, pois, nesta fase do inquérito, não sabemos que rumo deve tomar o interrogatório e o suspeito não deve aperceber-se da nossa ignorância." (FANON, 1980, p.76). Em seguida, Fanon (1980, p. 76) relata que a forma utilizada pelos torturados para quebrar a resistência era chamada de "preparação pelo exemplo".

O processo incluía a aplicação de técnicas de sofrimento físico e psicológico contra pessoas capturadas aleatoriamente nas ruas, levando as vítimas a um calvário que culminava no assassinato de cinco ou seis delas, diante $\operatorname{dos}($ as) patriotas que se queriam interrogar. Fanon refere-se a um segundo método, para dobrar a resistência dos prisioneiros e forçá-los, por meio da tortura, a comunicar o que as autoridades querem saber. Afirma Fanon (1980, p. 76) que "[...] são necessárias várias sessões para quebrar a sua energia. Nenhuma pergunta é posta ao suspeito." O informe de Fanon (1980, p. 76) menciona que "[...] o inspetor Podevin [...] confessa que é difícil náo dizer nada a partir do momento em que o torturado começa a pedir explicaçôes." As técnicas para quebrar a resistência do torturado devem levar a vítima ao limite: “[...] na sexta ou sétima sessão apenas lhe dizem: fala. Aqui o interrogatório não segue nenhuma orientação. Em princípio, o suspeito deve dizer tudo o que sabe." (FANON, 1980, p. 76).

Fanon colocou seu reconhecido talento como escritor a serviço da luta revolucionária. Os textos que produzia prestavam grandes contribuições à luta argelina e, inversamente, expunham a barbárie do colonialismo francês na Argélia. A intensidade do envolvimento de Fanon o tornou um homem perseguido. Colonialistas franceses e reacionários argelinos tentaram dar cabo de sua vida, levando-o a sofrer algumas tentativas de assassinato. Por segurança, houve momentos em que utilizou os pseudônimos de Dr. Fares e Dr. Omar (GEISMAR, 1972, p. 135, 163). 
O envolvimento de Fanon com a luta argelina ampliou-se durante a vivência revolucionária e ganhou novas dimensôes. Por força das atribuiçóes que recebera, viajou longamente pelo continente africano, onde vários países se encontravam em franco combate do colonialismo. Fanon estreitou laços de amizades com revolucionários de outros países africanos (talvez a mais célebre tenha sido com Patrice Lumumba, no Congo) e passou a perceber que havia um conjunto de povos em processos similares de retomada da liberdade. Essa sensibilização continental de Fanon transparece em vários textos que escreveu, dirigidos à juventude africana, e em outros, voltados aos africanos em seu conjunto.

Um artigo escrito desde uma perspectiva continental foi "Unidade e solidariedade efectiva são as condições da libertação africana"6 (FANON, 1980, p. 205), no qual transparece uma forte compreensão da geopolítica africana, naquele momento. Recorda as independências do Gana, da Guiné, dos Camaróes, do Togo, da Somália e da Nigéria, e observa que os representantes dos países colonialistas teciam discursos sugerindo que os povos africanos se acalmassem, pois a independência estava a caminho, pedindo que os africanos confiassem na boa vontade dos antigos senhores. Mas Fanon (1980, p. 205-206) desprezava essa sugestáo e enfatizava a importância do acirramento da luta.

Ademais, justifica que, naquele momento, os povos africanos não estivessem dando ouvidos aos conflitos Leste-Oeste. Segundo Fanon (1980, p. 207),

[...] quando nós, Africanos, dizemos que somos neutros quanto às relaçóes Leste-Oeste, queremos dizer que, de momento, a única questão que nos preocupa é a do nosso combate contra o colonialismo. [...] não somos de modo nenhum neutros perante o genocídio que a França faz na Argélia ou perante o apartheid na África do Sul.

Aluta contra o colonialismo era prioritária e requeria dos povos africanos, em combate ou não, uma firme solidariedade para a erradicação daquela doença político-social que os países europeus colonialistas implantaram no continente africano. Enfatiza Fanon (1980, p. 208) que "[...] a solidariedade interafricana deve ser uma solidariedade de facto, uma solidariedade de acção, uma solidariedade concreta em homens, em material, em dinheiro."

6 Publicado em El Moudjahid, n. 58, de 5 de janeiro de 1960. 
No final do artigo, Fanon (1980, p. 208) provoca a tomada de consciência do papel dos africanos a respeito do processo da própria libertação do colonialismo: “[...] nós, Africanos, dizemos que há mais de cem anos a vida de 200 milhóes de Africanos é uma vida depreciada, uma vida contestada, uma vida perpetuamente assombrada pela morte." Por isso, proclama a desconfiança "na boa-fé dos colonialistas" (FANON, 1980, p. 208) e, como alternativa, argumenta: "[...] devemos armar-nos de firmeza e de combatividade." (FANON, 1980, p. 208). Pregando o afastamento de tutelas ou parternalismos externos, Fanon professa a esperança da África libertada, sob a condução da própria gente africana. E acrescenta Fanon (1980, p. 208) que "[...] a África não será livre pelo desenvolvimento mecânico das forças materiais, mas é a mão do Africano e o seu cérebro que desencadeiam e levarão a bom termo a dialética da libertação do continente."

Como se depreende das leituras, a participação de Fanon nos serviços de imprensa da revolução argelina e das revoluçôes africanas representa uma contribuição à tomada de consciência da violência e barbárie configuradas no colonialismo. Sua intervenção jornalística consistiu num exercício de crítica e fomento do espírito libertário, decorrentes de sua opção radical pela vida humana, os quais fizeram dele a antítese inflexível do projeto colonial.

\section{Bioética global de Potter}

Bioética é um neologismo criado por Van Rensselaer Potter (1911-2001), da Universidade de Wisconsin, na cidade de Madison, nos EUA, em 1970. Depois de trabalhar mais de cinquenta anos na busca da cura do câncer, Potter reconheceu que um dos motivos pelo qual a ciência não a havia encontrado, ainda, era devido à especialização das ciências e ao modo disciplinar de sua organização. O reconhecimento dessa limitação das ciências fez Potter propor a bioética como um campo interdisciplinar de conhecimento. Nas palavras de Potter (2018a, p. 54): “[...] o maior impedimento para encontrar a solução para o câncer depende da organização da própria ciência, enquanto não integra as necessidades e opinióes dos cientistas e não cientistas, incluindo os pacientes e os cidadãos motivados.”

A necessidade que Potter vislumbra, quanto a uma nova ética para compor sua teoria bioética, emergiu, portanto, de sua práxis em meio a doentes de câncer, médicos e dramas humanos decorrentes da luta contra a dor, o sofrimento e a morte. Sua obra inicial, em 1971, intitulada Bioética, 
ponte para o futuro, levanta o debate sobre a necessidade de se repensar as práticas científicas e tecnológicas desvinculadas do mundo dos valores. Ao pensar a bioética como ponte entre ciências da vida (bios) com a sabedoria prática (ethos), Potter (2016) reforça que o distanciamento das ciências com as humanidades ameaça a sobrevivência humana no futuro.

Preocupado com as condiçóes necessárias à garantia da vida humana e do planeta, no futuro, Potter notou que o apelo contido no livro de 1971 não se propagou suficientemente, na sociedade e no meio científico, para assumir uma nova postura. Além disso, a própria expressão bioética passou a ser utilizada de modo reduzido, ou seja, para dar conta das relaçóes na prática médica. ${ }^{7}$ Entendida como ética médica, a bioética de Potter, nas suas duas primeiras décadas, ficou no anonimato (SGANZERLA; PESSINI; ZANELLA, 2019).

Decidido a alertar as sociedades sobre a urgência de reordenação dos parâmetros culturais, em vista da sobrevivência da vida na biosfera, Potter retoma seu ideal, em 1988, e redefine a bioética, intitulando-a de ideia da bioética global. Com ela, pretendia demonstrar que a saúde humana depende da saúde ambiental, social e cultural, e que a deterioração de uma das partes compromete a qualidade da vida do todo. Dessa forma, sustenta o autor, "[...] trata-se da necessidade de fazer da bioética médica complementar da bioética ecológica." (2018a, p. 163).

Anos mais tarde, ao reconhecer que a relação do ser humano com a natureza também tem a presença de elementos espirituais, e que a natureza é um bem e tem valor independente da atribuição dos valores pelos humanos, Potter, juntamente com seu discípulo Whitehouse, atribui à bioética global também a dimensão profunda, nomeando-a de bioética global e profunda. Ao tratar da bioética profunda, Potter e Whitehouse (2018, p. 202) afirmam que a "[...] bioética profunda versa sobre a sabedoria e o realismo náo otimista

7 O nascimento da bioética teve diferentes sentidos e paternidades. Primeiramente, em 1970, o bioquímico norte-americano, professor e pesquisador na área da oncologia, Van Rensselaer Potter, cunhou o neologismo bioética, denominando-a ciência de sobrevivência. Um ano depois, classificou-a como ponte para o futuro e, em 1988, como bioética global e profunda. Um ano depois, em 1971, um médico obstetra holandês, que trabalhava no atual Instituto Kennedy de Ética (Georgetown), usou a expressão bioética para fazer referência à ética médica, ou seja, para tratar da relação médico/ paciente. As pesquisas mais recentes de Rolf Lother (em 1997), da Universidade Humboldt de Berlim, encontraram nos periódicos da famosa Revista Kosmos que o teólogo alemão Fritz Jahr, em 1927, já tinha usado a expressão bioética para mostrar emergência de obrigaçôes éticas não apenas com os homens, mas com todos os seres vivos. Embora a bioética tenha essas diferentes paternidades, nesta reflexão, assumimos o sentido da bioética global proposta por Potter. 
e não pessimista, mas realismo." Por isso, acrescentam os autores, é preciso buscar a "[...] necessidade mais profunda, não a necessidade superficial concebida pelos gestores corporativos de dinheiro para o lucro a curto prazo ou a dos políticos que arrecadam dinheiro para a próxima eleição.” (POTTER; WHITEHOUSE, 2018, p. 202).

Assim, identifica-se que o conceito de bioética profunda emerge da percepção da natureza, enquanto um valor e um bem, mas que está ameaçado pela ação voraz do capitalismo e pela prática científica e tecnológica instrumental despreocupada com a sobrevivência humana no futuro. Dessa maneira, a bioética global e profunda avança em busca de diálogo com outras frentes de conhecimento, de modo a equipar as pessoas com um repertório conceitual capaz de lhes permitir o crescimento na consciência e no comprometimento com a busca do equilíbrio na ação. Nesse sentido, Potter e Whitehouse ressaltam a importância da sabedoria bioética de como usar o conhecimento para o bem social. Asseveram os autores: "[...] convocamos os leitores para a sabedoria bioética, que combinará o conhecimento ecológico com um senso de responsabilidade moral para um mundo habitável." (2018, p. 202).

Potter e Whitehouse conclamam todos os humanos e instituições a se envolverem num mutiráo planetário de responsabilidade pelo planeta e pela vida. Alertam para uma tragédia evitável que demanda todo o zelo ecológico possível. Trata-se de uma responsabilidade moral que recai sobre todos os indivíduos, universidades, corporaçôes, governos, instituiçôes não governamentais, até mesmo a religião. É preciso promover uma “[...] mudança na cultura, que deve ocorrer no início do século XXI, não como uma questão de responsabilidade moral do que devemos fazer, mas simplesmente como uma questão do que devemos fazer para sobreviver." (POTTER; WHITEHOUSE, 2018, p. 202).

Potter e Whitehouse destacam que, embora o conceito de bioética profunda tenha sido acrescido à bioética global somente mais tarde, essa concepção já se encontrava implícita na intuição original da categoria bioética. Dessa vez, evidencia-se a premência da cooperação dos diversos campos do saber em vista de uma ética global, a qual subsidie a ação humana consistente e ecológica e socialmente responsável, em face da responsabilidade pelas geraçôes futuras ameaçadas pela forma predatória de exploração ambiental. 
A bioética global e profunda opera numa perspectiva de conjunto, traçando linhas de ação com vistas a um resultado de libertação planetária. A reestruturação da cultura teria um papel relevante para fomentar a conscientização e a mudança de condutas motivadas pelo respeito à vida e a responsabilidade pelas geraçóes futuras.

Com a bioética global e profunda, Potter quer libertar a natureza dos interesses imediatos do ser humano. Se o modelo de produção de consumo do sistema capitalista escraviza tanto o ser humano como a natureza, ressaltam Potter e Whitehouse (2018, p. 204), é preciso encontrar "[...] caminhos para impedir o impulso capitalista de explorar o sistema livre de mercado com a globalização das forças econômicas que não possuem responsabilidade global.” Para os autores o "[...] atual nível de consumo é imoral [...] e desnecessário em nível global” (POTTER; WHITEHOUSE, 2018, p. 204- 205), por isso é condenado pela bioética. Destacam também os autores que "[...] os estilos de vida da população mundial podem permanecer diversos e ainda serem compatíveis com uma biosfera estável." (POTTER; WHITEHOUSE, 2018, p. 202). A bioética global e profunda, frisa Sganzerla (2018, p. 1), "[...] mostrou que um novo mundo é possível de ser construído, com respeito às pessoas, às culturas e em harmonia com a natureza." Uma natureza empobrecida gera também o empobrecimento do próprio ser humano, o que faz com que o bem-estar humano não possa ser concebido independentemente do ambiente no qual ele está inserido. Ou seja, o ambiente humano e o ambiente natural se degradam conjuntamente e, por isso, não é possível enfrentar a degradação ambiental, sem considerar a degradaçáo humana e social.

Com a bioética global e profunda, Potter mostrou a existência de uma relação direta entre os elementos antropológicos, cósmicos e ecológicos, exigindo, dessa forma, a superação das concepçôes reducionistas e materialistas de seu tempo, que visam a resultados imediatos ao ser humano.

\section{Consideraçóes Finais}

Ao término desta reflexão, que buscou uma identificação entre a práxis jornalística de Fanon, na luta por justiça social e libertação do povo argelino, com a concepção de bioética global proposta por Potter, preocupado com o futuro da sobrevivência humana no planeta, devido à ação predatória do ser humano sobre o ambiente, e com os avanços da tecnociência sem o devido parâmetro ético, pode-se afirmar que, embora os autores tenham tido motivaçóes diferentes, em 
ambientes e contextos históricos e sociais divergentes, há um substrato comum entre ambos, o qual permite fazer essa aproximação.

O reconhecimento de Fanon de que a violência vivida pelos argelinos, durante a prática colonialista, era a causa de adoecimento físico e mental daquele povo e que, portanto, não era possível tratar de sua saúde sem libertarse da dominação dos colonizadores, identifica-se com a concepção de bioética global de Potter, quando este reconhece que a saúde humana está diretamente relacionada à saúde ambiental, cultural e social.

Fanon buscou mostrar esse vínculo, através de ação política, médica e, sobretudo, com seus escritos no jornal El Moudjahid, os quais representaram um verdadeiro remédio para a libertação daquele povo, na medida em que suas palavras davam voz, poder e força para lutar contra a doença, que, no caso, era a opressão dos colonizadores. Potter, por sua vez, diante da ameaça da continuidade da vida humana no futuro, com sua bioética global, procura libertar a natureza dos interesses imediatos do ser humano. Nessa libertação planetária, a cultura tem um papel fundamental, pois é preciso conscientizar o ser humano para a fragilidade da vida da biosfera e, consequentemente, exigir a prática da responsabilidade para com as geraçóes futuras. A criação da cátedra do futuro, realizada por Potter, como espaço interdisciplinar para refletir sobre o futuro da humanidade, mostra a preocupação e o compromisso do cientista com a vida.

Opondo-se ao modo convencional de pensar da época, que defendia uma ciência livre de valores, Potter faz da ética a base da sua proposta bioética, ou seja, o remédio para a libertaçáo planetária. Trata-se de uma ética de caráter pragmático, porque o cientista não queria limitar-se a um discurso ético, mas incluir uma prática, um compromisso como bem destaca seu credo bioético presente nas suas obras. Esse compromisso de libertação planetária Potter o defendeu, com ações e palavras, até o fim da sua vida, como é possível identificar em seu discurso no Congresso Mundial de Bioética (Espanha 2000), quando ele conclama a todos para que se tornem "[...] politicamente ativos"(2018a, p. 255), não no sentido partidário, mas como um “[...] atitude interior dos indivíduos que ao olhar para um objetivo distante, são capazes de realizar ações em tal direção" (POTTER, 2018a, p. 56), de sorte a impedir que as ameaças se concretizem.

A comparação de Potter de que a ação humana sobre a natureza se assemelha à ação das células cancerígenas agindo sobre o corpo humano, 
levando-o à morte, muitas vezes, de modo silencioso e imperceptível, aplicase à prática colonialista dos franceses sobre os argelinos, denunciada por Fanon, porque, embora aquele povo pudesse até reconhecer a dominação e a exploração física que sofria, era incapaz de identificar a dominação mental, e nem mesmo tinha consciência de tal dominação.

O jornalismo revolucionário praticado por Fanon, durante a revolução argelina, comunga da bioética global de Potter também na crítica ao capitalismo predatório, quando este afirma que a humanidade não pode mais submeter-se "[...] à santidade do dólar" (2018a, p. 69), pois esse modo de pensar degrada a biosfera e a dignidade humana. Fanon, por sua vez, ao tratar da exploração da terra e da escravidáo imposta pelos franceses, relata que estes instauraram o terror contra as pessoas que resistiam à usurpaçáo de seus direitos. Seus escritos jornalísticos, como forma de denúncia, mobilização e conscientização daquela realidade, constituíram uma das estratégias encontradas por Fanon para enfrentar aquele contexto.

Ao tratar da condenaçáo de Djamila Bouhired, o texto de Fanon assegura que ela era inocente das acusaçóes que lhe fizeram. No entanto, o sistema judicial comprometido com o colonialismo condenou-a à morte, o que demonstra a fragilidade da ciência jurídica, distanciada da justiça e da verdade. A mesma dominação sem a proteção da ciência jurídica ocorre, segundo Potter, em relação à natureza, quando poderosos grupos econômicos, apoiados na santidade do dólar, se impóem sobre a normatização jurídica em relação à proteção do meio ambiente.

Se, por um lado, a bioética global convoca às variadas expressóes dos conhecimentos científicos e tecnológicos, bem como das religiōes, em benefício do zelo planetário e da defesa da vida, em vista da sobrevivência humana futura, Fanon, em sua intervenção jornalística, articulou os saberes médicos, filosóficos, geográficos e políticos, dentre outros, em benefício da reeducação do público leitor, em vista da liberdade possível e da erradicação do colonialismo imperdoável.

A carta de demissão enviada ao Ministro Residente, Robert Lacoste, em 1956, explicita a opção radical de Fanon pelo ser humano, pelo reconhecimento da dignidade radical da pessoa humana, negada em termos absolutos pelos colonialistas franceses, na Argélia. Nesse sentido, Fanon antecipava a inquietação de Potter para com a humanidade do futuro, 
ameaçada de extinção devido à ação do capitalismo consumista, energívoro e esbanjador do tempo presente.

Para concluir, evidencia-se um paradoxo entre a práxis libertária de Fanon, em suas atividades jornalísticas, e a colonialidade neoliberal assumida por grandes meios de comunicação brasileiros, nos últimos anos. Enquanto as opçóes de Fanon contra a colonialidade exigiram dele a utilização de pseudônimos e até da clandestinidade, profissionais e grupos de comunicação, no Brasil, assumem o vigoroso compromisso com as forças da colonialidade, com opçóes político-ideológicas em vista dos interesses imediatos do capital. Sua ganância por poder e, consequentemente, por resultados econômicos imediatos, impede-os de pensar na sobrevivência humana no futuro, opondose, desse modo, também aos ideais da bioética global de Potter.

SGANZERLA, A.; QUEIROZ, I. P.; SILVA, R. S. Fanon, journalist of social justice and liberation and their approaches to Potter global bioethics. Trans/Form/Açáa, Marília, v. 45, p. 185-206, 2022. Edição Especial.

\begin{abstract}
The big communication corporations of Brazil operate as constructers of meaning trough syntonized narratives in behalf of groups and social players, and with contempt for the rights and demands of popular sectors. A similar communication practice was experienced by Frantz Fanon in Africa. However, the activist was able to make an instrument in service of justice and liberation of oppressed African people from his journalistic practice. This libertarian practice of Fanon identifies oneself with the subsequently created global bioethics of Van Rensselaer Potter. In the face of this scenario, this reflection wants to investigate in what sense the journalistc praxis of Fanon during the Argelian Revolution, in pursuit of social justice and liberation, identifies itself with the global bioethics principles later proposed by Potter? The analyses consists in an anaclitic deductive character. If with global bioethci Potter searched to restore a human sense of the technological and scientific praxis, Fanon seeked this goal as an social communicator and physician.
\end{abstract}

Keywords: Global bioethics. Journalism. Social Justice. Liberation. 


\section{REFERÊNCIAS}

BONINI, A. O jornal escolar como mídia contra-hegemônica - jornalismo de escola não modelado pelo jornalismo comercial dominante. Linguagem em (Dis)curso - LemD, Tubarão, SC, v. 17, n. 2, p. 165-182, maio/ago. 2017.

BURKE, P. A. Comunicação na História. In: RIBEIRO, A. P. G.; HERSCHMANN, M. (org.). Comunicaçáo e história: interfaces e novas abordagens. Rio de Janeiro: Mauad X/ Globo Universidade, 2008. p. 61-82.

BURKE, P.; BRIGGS, A. Uma história social da mídia: de Gutenberg à internet. Rio de Janeiro: Jorge Zahar, 2006.

ECO, U. Apocalípticos e integrados. São Paulo: Contexto, 2004.

FANON, F. Em defesa da revoluçáo africana. Lisboa: Sá da Costa, 1980.

GEISMAR, P. Fanon. Traducción de Marta Mastrogiacomo. Buenos Aires: Granica, 1972.

GENRO FILHO, A. O segredo da pirâmide: para uma teoria marxista do jornalismo. Porto Alegre: Tchê, 1987.

LAGE, N. A reportagem: teoria e técnica de entrevista e pesquisa jornalística. Rio de Janeiro: Record, 2011.

MARCONDES FILHO, C. O capital da notícia: jornalismo como produção social da segunda natureza. São Paulo: Ática, 1989.

MATTELART, A. A globalizaçáo da comunicaçáo. Bauru-SP: EDUSC, 2002.

MEDINA, C. Notícia: um produto à venda. São Paulo: Alfa-Ômega, 1988.

MOTTA, L. G. Notícias do Fantástico. São Leopoldo: Unisinos, 2006.

POTTER, V. R. Bioética global: construindo a partir do legado de Leopold. Tradução de Cecília Camargo Bartalotti. São Paulo: Loyola, 2018.

POTTER, V. R. Bioética: ponte para o futuro. Tradução de Diego Carlos Zanella. São Paulo: Loyola, 2016.

POTTER, V. R. Um encontro com Van Rensselaer Potter. (Entrevista concedida a Sandro Spinsanti) In PESSINI, L.; SGANZERLA, A.; ZANELLA, D. (org.). Van Rensselaer Potter: um bioeticista original. São Paulo: Edições Loyola, 2018a, p. 49-59.

POTTER, V. R. Temas bioéticos para o século XXI. In PESSINI, L.; SGANZERLA, A.; ZANELLA, D. (org.). Van Rensselaer Potter: um bioeticista original. São Paulo: Loyola, 2018b. p. 243-251.

POTTER, V. R. A bioética global diante de um mundo de crise. In PESSINI, L.;

SGANZERLA, A.; ZANELLA, D. (org.). Van Rensselaer Potter: um bioeticista original. São Paulo: Loyola, 2018c. p. 63-74. 
POTTER, V. P.; WHITEHOUSE, P. J. Bioética profunda e global: para um terceiro milênio habitável. In PESSINI, L.; SGANZERLA, A.; ZANELLA, D. C. (org.). Van Rensselaer Potter: um bioeticista original. São Paulo: Loyola, 2018. p. 201- 205.

SHUDSON, M. Descobrindo a notícia: uma história social dos jornais nos Estados Unidos. Petrópolis: a Vozes, 2010.

SGANZERLA, A. Por uma bioética profunda e global e o diálogo entre as ciências da vida e a sabedoria prática (2018). Disponível em http://www.ihu.unisinos.br/159noticias/entrevistas/580198-a-bioetica-potteriana-um-dialogo-entre-as-ciencias-da-vida-ea-sabedoria-pratica-entrevista-especial-com-anor-sganzerla/ - Acesso em: 10 ago. 2020.

SGANZERLA, A.; PESSINI, L.; ZANELLA, D. A bioética global de V. R. Potter. Ambiente \& Sociedade. São Paulo, v. 22, p. 1- 8, 2019.

STEPHENS, M. História das comunicaçóes: do tantá ao satélite. Rio de Janeiro: Civilização Brasileira, 1993.

TRAQUINA, N. Teorias do jornalismo: a tribo jornalística, uma comunidade interpretativa transnacional. V. II. Florianópolis: Insular, 2005.

Recebido: $15 / 8 / 2020$

Aceito: 11/3/2021 